This example is similar to those interactions in Drosophila in which the heterozygotes represented as $t_{1}+_{2} / m_{1} m_{2}$ and $+_{1} m_{2} / m_{1}+_{2}$ ( $m$ designates the mutant form) are not equivalent in action. Like the $A^{b}$ locus ${ }^{4}$ in maize, physically distinct units function co-operatively in the determination of an effect.

The observation is of particular interest owing to the implication that the proximity of these loci concerned with distribution of pigment is not fortuitous.

A fuller account of this work will be published elsewhere with my colleague D. H. Long, who recorded this progeny at the Agricultural Research Council's Potato Genetics Research Station in Cambridge.

John Innes Horticultural Institution,

KENNETH S. DodDS

Bayfordbury,

Hertford, Herts.

Nov. 2.

1 Dodds, K. S., and Long, D. H., J. Genet. (in the press).

${ }^{2}$ Hawkes, J. G., I.A.B. Bull., pp. 142 (1944).

${ }^{3}$ Lewis, W. B., Genetics, 33, 113 (1948). Green, M. M., and Green, K. C., Proc. U.S. Nat. Acad. Sci., 35, 586 (1949).

‘ Laughnan, J. R., Proc. U.S. Nat. Acad. Sci., 35, 167 (1949).

\section{Hereditary (Seed-borne) Symbiosis in Ardisia humilis Vahl.}

STEVENSON ${ }^{1}$ recorded bacterial symbiosis in some New Zealand plants, Singh ${ }^{2}$ noticed bacteria in stems, leaves and flowers of a number of angiospermic plants in South India, and Heimbeck ${ }^{3}$ recently reported the occurrence of $L$ forms of bacteria in wilting pea, which are filtrable through membranes that retain the smallest bacteria.

In Ardisia humilis (Myrsinacea) growing in the Carmichael Medical College garden, schizogenous glands are found in leaves, stems, roots, floral envelopes (calyx and corolla), stamens, styles and in endosperms of seeds. $B$. type $L$ forms of bacteria are found in large numbers close to these glands, and a pinkish colour is very noticeable in young leaves (especially at their margins), sepals, petals, anthers, carpels and seeds. Roots have conspicuous irregular nodular swellings due to infection by bacteria, and leaves, sepals and petals bear a large number of glands. The plants are perfectly healthy, they have grown for more than twenty years in the College garden and normally bear abundant lilac-coloured flowers and fruits. In fact, $B$. type $L$ forms of bacteria are found in every part of the plant, especially in growing regions and organs. Bacteria were aseptically isolated from leaves and roots and were grown in pure culture in nutrient agar, malt-agar and in liquid malt, when a large number of $L$ bodies similar to those photographed by Heimbeck (Fig. Nos. 7-11) ${ }^{3}$ were found along with the bacteria in the form of small granules. The $L$ forms were found to grow in small colonies without exuding mucilage or slime, their colonies forming each a dark central portion surrounded by lighter peripheral zone. Such forms are regarded by Kleineberger-Nobel ${ }^{4}$ as forms intermediate between virus and bacteria.

Pohjakallio et al. ${ }^{5}$ remark that micro-organisms (in their case, one Pseudomonas sp.) may antibiotically limit the damage caused by clover-rot fungus (Sclerotinia trifoliorum Erikss.) to clover, Trifolium pratense.

The red colour from leaves, roots, anthers, etc., can be extracted easily with absolute alcohol.
Absorption spectra of this colour and its chemical characters are being studied with the view of finding out if it contains hrmin and also if this colour is the metabolic product of $L$ type organisms. The results of this study will be described in due course.

\section{S. R. Bose}

Botanical Laboratory,

Carmichael Medical College, Calcutta.

Oct. 26.

'Stevenson, G. B., Ann. Bot., N.S., 17, 343 (1953).

'Singh, T. C. N., Ind. Sci. Congress Proc., Lucknow (1953); also Ind. Sci. Congress Proc. (1950 and 1951).

' Heimbeck, J.. S., "On the Etiology of Brown Roots, Yellowing and Wilt due to 'B. type $L$. Forms' of Bacteria, with special reference to Pea-Wilt" (Levanger, Norway, 1954).

4 Kleineberger-Nobel, E., Biol. Rev., 29, 154 (1954).

¿ Pohjakallio, 0 ., Salonen, A., and Relander, E., Acta Agric Scand.. $3,53(1953)$.

\section{Blood Supply of Mystacial Vibrissæ}

Current interest in the blood supply to the skin and hair follicles of the sheep ${ }^{1,2}$ prompts description of some recent investigations into the blood supply to the mystacial vibrissæ of the cat and rat. The animals were killed with ether and amyl nitrite, or intraperitoneal 'Nembutal', and a polythene cannula introduced into either the common carotid artery or jugular vein. Blood was washed out with warm normal saline containing sodium nitrite or with 'Priscol', a sympathetic blocking agent. A warm 2 per cent aqueous solution of soluble Berlin blue was the best of the injection masses used, due to its small particle-size and low viscosity. Techniques dependent on the presence of hæmoglobin did not reveal the fine vessels traversing the trabeculæ because they were obscured by blood in the sinuses, while constricted vessels empty of blood were overlooked.

Observation on injected mystacial pads fixed either in 80 per cent alcohol and cleared by the method of Spalteholz, or in formal-saline and sectioned on the freezing microtome at $100-150 \mu$, show a main artery approaching the side of each follicle. This gives branches to the striated muscles of adjacent follicles, and to a capillary plexus between the necks of the follicles, and then accompanies the sensory nerve passing through the outer dermal sheath at an angle of about $45^{\circ}$. At the inner limit of the middle dermal sheath it divides into three branches (Fig. 1). The first, a fine vessel, turns sharply to the base of the follicle and contributes to a capillary network which extends to the hair matrix. A second, larger branch contributes to the capillary network of the middle region of the follicle, anastomosing with the first branch. The third passing superficially gives rise to capillaries encircling the hyaline membrane reaching up to the deeper part of the ringwulst, from which region some of the injection mass could usually be seen escaping into the upper part of the cavernous sinus. The injection mass never passed readily into the sinuses, which always contained blood even when an otherwise complete injection of the mystacial region had been accomplished.

The efferent drainage of the follicle, the existence of which has not previously been reported, consists of a number of fine vessels (diameter c. $4 \mu$ ) arising adjacent to the hyaline membrane and joining to form three principal vessels also of capillary dimensions (Fig. 2). These unite and pass through the outer 